\title{
Variation of axillary growth as respond of Morus spp. micropropagation using various concentration of Indonesian local solid substance
}

\author{
YASINTA RATNA ESTI WULANDARI", LAURENSIA DANIS ANGGRADITA \\ Department of Biology, Faculty of Biotechnology, Atma Jaya Catholic University of Indonesia. BSD Campus, Jl. Raya Cisauk-Lapan No. 10, BSD City, \\ Tangerang 15345, Banten, Indonesia. Tel.: +62-21-80827200 (ext. 1039), "email: yasinta.ratna@ atmajaya.ac.id
}

Manuscript received: 28 August 2019. Revision accepted: 7 December 2019.

\begin{abstract}
Wulandari YRE, Anggradita LD. 2020. Variation of axillary growth as respond of Morus spp. micropropagation using various concentrations of Indonesian local solid substance. Biodiversitas 21: 80-85. The difficulties of growing Morus spp. makes it become one local plant that hard to cultivate conventionally even though it's a beneficiary plant. Hence cultivation Morus spp. through tissue culture technique could help growing this plant. This research is aimed to design the optimal condition for micropropagation of local Morus spp. (Morus bombycis var. lembang, M. cathayana, M. multicaulis, and M. alba var. kanva-2) using agar-agar as Indonesian local solid substance. This solid substance is used as its cheap and easy to find compared to other solid substances. This research used MS medium supplemented with $0.1 \mathrm{ppm}$ naphthalene acetic acid $+1.0 \mathrm{ppm}$ benzyl aminopurine and various concentration of agar-agar $(0.6 \%, 0.8 \%, 1.0 \%)$. Growth rate, axillary bud length and number, leaf number, callus formation and contamination were observed in this research. All those concentrations could be used for micropropagation of Morus spp. Agar concentrations of 0.8 and $1.0 \%$ showed better results than $0.6 \%$ because it showed the highest results.
\end{abstract}

Keywords: Morus alba var. kanva-2, Morus bombycis var. lembang, Morus cathayana, Morus multicaulis, solid substance

\section{INTRODUCTION}

Indonesia is one of the countries that provide appropriate environment for Mulberry (Morus spp.) to grow. Morus spp. has flowers and fruit and each component of this tree is useful for humans (Tuigong et al. 2015). The leaf contains a lot of active compounds and vitamins that can be used as a medicine (Wulandari et al. 2019). The branch is strong which can be used as a badminton racket. Fruit produced also has active compound that can be used for curing many diseases.

Morus spp. is different in morphology for each place. There are a lot of different species in Indonesia and each species needs different environments to grow. It depends on plant's cultivar, genotype, and environment (Gogoi et al. 2017). Bogor, West Java is one of the places providing the growth of Morus spp.. Morus bombycis var. lembang, Morus cathayana, Morus multicaulis, and Morus alba var. kanva-2 are the Mulberry species that have been cultured in Bogor since a long time ago. Because of its beneficiary, many people trying to culture Morus spp. although it is hard to do. Morus spp. only lives in a place with high altitude, humidity, and high level of rainfall. It takes a long time to grow, large field, and easy to be infected by pests. These properties make conventional methods not feasible anymore (Vijayan et al. 2011).

Plant tissue culture techniques are the alternative way to grow Morus spp. outside its natural environment. By culturing certain parts of plant in agar medium that contain plant growth regulator, it will expedite and simplify the cultivation of Morus spp. Solid substance is one of important substances contained in agar medium. Solid substance takes a big role in solidifying and maintaining both physiological and biological states. It affects the morphogenesis and growth of plants and its composition helps to fulfill the nutrition of plants and reduces contamination rate (Buah et al. 1999). The concentration of solid substances plays a big role in plant tissue culture. Media that is too soft could produce hyper-hydricity where if it is too hard may reduce plant growth (Gangophadhyay et al. 2009).

Solid substances that usually used are synthetic and imported hence it takes higher cost. There is some natural ingredient that can be used for solidifying like starch from tuber plant however the clarity is still low and need a lot of labor work (Priadi et al. 2008). Food grade agar also can be used for solidifying medium (Petrovski and Tillet 2012). Using Indonesian local food grade agar has been conducted before for strawberry plants (Agustiansyah 2002).

Agar-agar is local food grade agar made from red seaweed gel-forming polysaccharide. It is composed of repeating agarobiose units. It is solidified the medium by binding the hydroxyl group to water (Praiboon et al. 2006). Agar contains carbohydrate which provides organic and inorganic compound for culture's medium. Best concentration of agar-agar is $0.6-1 \%$. This research has been conducted for strawberry plants before (Agustiansyah 2002). Compare to synthetic agar, agar-agar can be used as a natural solid substance. It is easy to find, cheap, and supports the growth of the plant well. 
The aim of this research was to get the best concentration of agar-agar for local Morus spp. propagation (Morus bombycis var. lembang, Morus cathayana, Morus multicaulis and Morus alba var. kanva-2) with plant tissue culture technique and determining the best species for growing Morus spp. with plant tissue culture techniques.

\section{MATERIALS AND METHODS}

\section{Materials and instruments}

This research used two years old mulberry that originated from University Farm of IPB University, Sukamantri, Bogor, West Java and had been rejuvenated (M. alba var. kanva-2, M. bombycis var. lembang, $M$. multicaulis, and M. cathayana). The sample was taken in September and November 2017. The medium was made with Murashige and Skoog (MS), benzyl aminopurine (BAP) (Sigma Aldrich), naphthalene acetic acid (NAA) (Sigma Aldrich), and agar-agar with variated concentration $(0.6 \%, 0.8 \%$, and $1.0 \%)$, commercial sodium hypochlorite, commercial detergent, Tween ${ }^{\circledR} 20$, Dithane M-45, 70\% and $96 \%$ alcohol, and distillate water.

The equipment used in this research was analytic weight, beaker glass, $\mathrm{pH}$ meter, stirrer and heater, petri dish, filter paper, small jar, tweezers, scalpel, aluminum foil, and measuring glass. Few instruments including laminar airflow cabinet, oven, and autoclave also were used.

\section{Procedures}

Procedures

Indonesian local agar-agar with range concentration $(0.4,0.6,0.8,1.0$ and $1.2 \%)$ was used for this research. Medium with those range of concentration was made, and one axillary bud was planted. The morphology and clarity were observed and three best concentration was chosen.

\section{Initiation}

Morus spp. stem that has one axillary bud was sterilized and planted on jar contained MS medium supplemented with the various concentration of agar-agar $(0.6 \%, 0.8 \%$, and $1.0 \%)$ and plant growth regulator (PGR) (0.1 ppm $\mathrm{NAA}+1.0 \mathrm{ppm}$ BAP). Sterilization method was based on Anggraini (2015). Each jar contained one explant and was replicated three times. Explant then was stored under the fluorescent lamp with $20 \mathrm{~cm}$ as the distance. Explant was incubated on culture room with $56 \%$ humidity. The temperature was maintained $22.2^{\circ} \mathrm{C}$.

\section{Design of experiment}

The experiment was conducted in completely randomized design with three replications. This experiment used 2 factorial patterns. The first factor was species of the plant: (i) S1: M. Multicaulis, (ii) S2: M. cathayana, (iii) S3: M. alba var. kanva-2, (iv) S4: M. bombycis var. lembang. The second factor was the concentration of solid substance: (i) S1: $0.6 \%$ agar-agar, (ii) $\mathrm{S} 2: 0.8 \%$ agar-agar, (iii) $\mathrm{S} 3$ : $1.0 \%$ agar-agar.
Table 1. The characteristic of each concentration of agar-agar

\begin{tabular}{cl}
\hline Concentration & Characteristic \\
\hline $0.4 \%$ & Liquid, could not sustain the plant \\
$0.6 \%$ & Solid, easy to be planted, sustained the plant \\
$0.8 \%$ & Solid, easy to be planted, sustained the plant \\
$1.0 \%$ & Solid, easy to be planted, sustained the plant \\
$1.2 \%$ & Solid, hard to be planted \\
\hline
\end{tabular}

Growth rate, axillary bud length and number, leaf number, callus formation and contamination are observed. The observation was done once every three days for one month.

\section{Data analysis}

Results were analyzed with SPSS. Statistical analysis method that had been used was Analysis of Variance (ANOVA) if the results were normally distributed.

\section{RESULTS AND DISCUSSION}

\section{Agar-Agar concentration}

Mulberry was planted on different concentrations of agar-agar to know the concentration range that can support the plant. Agar-agar showed different morphology for each concentration (Table 1). The best concentration was around $0.6-1.0 \%$. Less than $0.6 \%$ concentration agar-agar showed that medium becomes watery and failed to sustain the plant. However, concentration of more than $1.2 \%$ cannot be used due to high viscosity.

Based on the characteristics of each concentration of agar-agar (Table 1), concentration lower than $0.6 \%$ could not be used because it did not solidify. The concentration higher than $1 \%$ made the medium became too solid. It might inhibit the nutrition flow on medium. This result corresponded with previous research where the good concentration for agar-agar was $0.6 \%-1 \%$ (Agustiansyah 2002). The concentration of agar-agar that had been used in this research was $0.6 \%, 0.8 \%$, and $1.0 \%$.

\section{Initiation}

Each concentration of agar began to show different results after $3^{\text {rd }}$ week of incubation (Figure 1). Morus cathayana planted at $0.8 \%$ agar showed the highest growth. On the other hand, $0.8 \%$ M. multicaulis did not show a good result.

The in vitro growth of each explant showed different axillary growth between culture grown on agar gelled media (Figure 1). Different agar concentration affects plant growth and sometimes leads to somaclonal variation (Sulusoglu 2014). Somaclonal variation associated with the variability of cultivar, PGR, and age of the cultivar in culture. The chemical substances in the medium also enhance the rate of genetic variation of the plant. Some changes occurred during planting or callus development stage (Kasim et al. 2017; Navroski et al. 2014). The longer culturing the plant in vitro could enhance the possibility of 
somaclonal variation. The changes are related to oxidative stress due to changes in the environment or explant preparation. This oxidative stress leads to production of free radicals that promote genetic mutation of the plant (Krishna et al. 2016). It also relates to different ages of parental that might attribute to a different growth rate (Ngezahayo and Liu 2014). The same planting and explant sources are important to avoid genetic changes. Old plant uses nutrition for secondary metabolic production rather than primary growth. Using young plant as the explant source is better. Season changing also affects the growth of the plant. In the rainfall season, plants tend to growth the primary organ. Varying responses to this research also related to contamination rate and browning.

The growth of Morus spp. stagnated after three weeks of planting. It might attribute to decreasing nutrition and subculture could help to prevent this. Aga and Khillare (2017) found that the best growth would be shown at three weeks of planting. After that, explant would start to deteriorate or the growth would be stagnated. In this research, the growth rate of $M$. bombycis var. lembang (0.6\% and $1.0 \%)$, M. cathayana $(0.6 \%$ and $0.8 \%), M$. multicaulis $(0.6 \%$ and $1.0 \%)$, and $M$. alba var. kanva-2 $(1.0 \%)$ increased on the last week. It might happen because of the photosynthesis rate of Morus spp. increased and the plant had used all nutrition on medium so the growth difference was caused by genetic of plant (Huh et al. 2017; Yelli 2013).

Each concentration showed different growth for each explant (Figure 2). M. bombycis var. lembang and $M$. cathayana showed good results for the length of axillary bud on the concentration of $0.8 \%$ agar-agar (Table 2). $M$. multicaulis and M. alba var. kanva-2 showed good results on $1.0 \%$ agar-agar. The highest number of axillary buds was observed on $1.0 \%$ agar-agar except for $M$. alba var. kanva-2 where the best result was obtained with $0.6 \%$ and $0.8 \%$ agar-agar. The highest number of leaves was obtained with $1.0 \%$ agar-agar except for M. multicaulis, where $0.6 \%$ agar-agar showed the best result.

Each concentration of agar-agar showed callus development for $M$. bombycis var. lembang and $M$. cathayana (Table 3). M. multicaulis and M. alba var. kanva-2 with $0.8 \%$ agar-agar did not show any callus development. The highest contamination rate was exhibited by $M$. multicaulis and the most unsusceptible explant was M. alba var. kanva-2.

Table 2. Effect of agar-agar on growth of axillary bud and leaf of Morus spp.

\begin{tabular}{|c|c|c|c|c|}
\hline Species & $\begin{array}{l}\text { Agar } \\
\text { conc. }\end{array}$ & $\begin{array}{c}\text { Axillary } \\
\text { bud length } \\
\text { (cm) }\end{array}$ & $\begin{array}{c}\text { Axillary } \\
\text { bud } \\
\text { number }\end{array}$ & Leaf number \\
\hline \multirow{3}{*}{$\begin{array}{l}\text { M. bombycis } \\
\text { var. lembang }\end{array}$} & $0.6 \%$ & $0.87 \pm 0.43^{\mathrm{a}}$ & $1.33 \pm 0.33^{\mathrm{a}}$ & $2.00 \pm 1.16^{\mathrm{a}}$ \\
\hline & $0.8 \%$ & $1.17 \pm 0.20^{\mathrm{a}}$ & $1.00 \pm 0.00^{\mathrm{a}}$ & $3.00 \pm 1.53^{\mathrm{a}}$ \\
\hline & $1.0 \%$ & $0.97 \pm 0.20^{\mathrm{a}}$ & $1.67 \pm 0.33^{\mathrm{a}}$ & $3.33 \pm 1.67^{\mathrm{a}}$ \\
\hline \multirow{3}{*}{ M. cathayana } & $0.6 \%$ & $1.20 \pm 0.21^{\mathrm{a}}$ & $1.00 \pm 0.00^{\mathrm{a}}$ & $2.00 \pm 1.16^{a}$ \\
\hline & $0.8 \%$ & $1.73 \pm 0.45^{\mathrm{a}}$ & $1.00 \pm 0.00^{\mathrm{a}}$ & $4.00 \pm 0.00^{\mathrm{a}}$ \\
\hline & $1.0 \%$ & $1.13 \pm 0.12^{\mathrm{a}}$ & $2.00 \pm 0.58^{\mathrm{a}}$ & $5.67 \pm 1.76^{\mathrm{a}}$ \\
\hline \multirow{3}{*}{ M. multicaulis } & $0.6 \%$ & $0.67 \pm 0.20^{\mathrm{a}}$ & $1.00 \pm 0.00^{\mathrm{a}}$ & $0.67 \pm 0.67^{\mathrm{a}}$ \\
\hline & $0.8 \%$ & $0.40 \pm 0.21^{\mathrm{a}}$ & $1.00 \pm 0.00^{\mathrm{a}}$ & $0.00 \pm 0.00^{\mathrm{a}}$ \\
\hline & $1.0 \%$ & $0.83 \pm 0.38^{\mathrm{a}}$ & $1.00 \pm 0.00^{\mathrm{a}}$ & $0.00 \pm 0.00^{\mathrm{a}}$ \\
\hline \multirow{3}{*}{$\begin{array}{l}\text { M. alba var. } \\
\text { kanva-2 }\end{array}$} & $0.6 \%$ & $0.30 \pm 0.12^{\mathrm{a}}$ & $1.33 \pm 0.33^{\mathrm{a}}$ & $1.33 \pm 0.88^{\mathrm{a}}$ \\
\hline & $0.8 \%$ & $1.03 \pm 0.27^{\mathrm{a}}$ & $1.33 \pm 0.33^{\mathrm{a}}$ & $3.33 \pm 0.33^{\mathrm{a}}$ \\
\hline & $1.0 \%$ & $1.13 \pm 0.32^{\mathrm{a}}$ & $1.00 \pm 0.00^{\mathrm{a}}$ & $4.33 \pm 0.88^{\mathrm{a}}$ \\
\hline
\end{tabular}

Results are shown as means \pm SE. Mean followed by the same letter in each column of same species is not significantly different at $p<0.05$ by One Way ANOVA test.

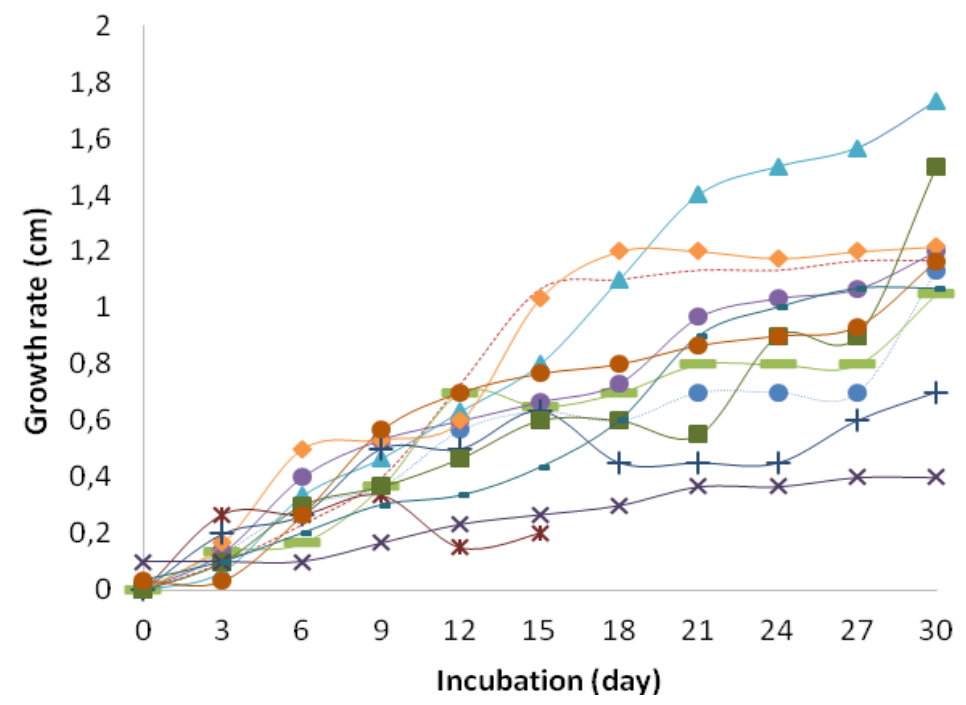

Figure 1. Axillary growth on each concentration of agar-agar

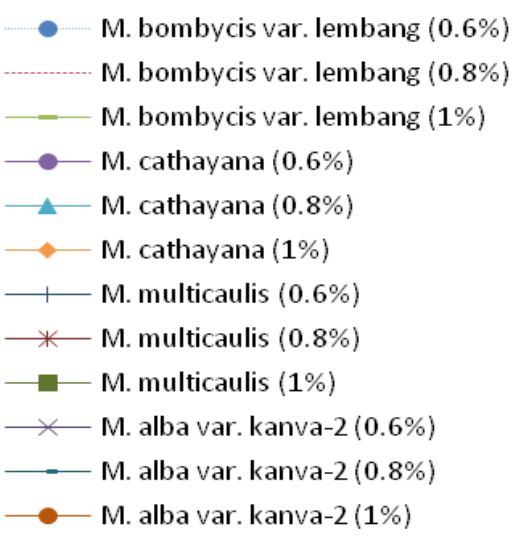




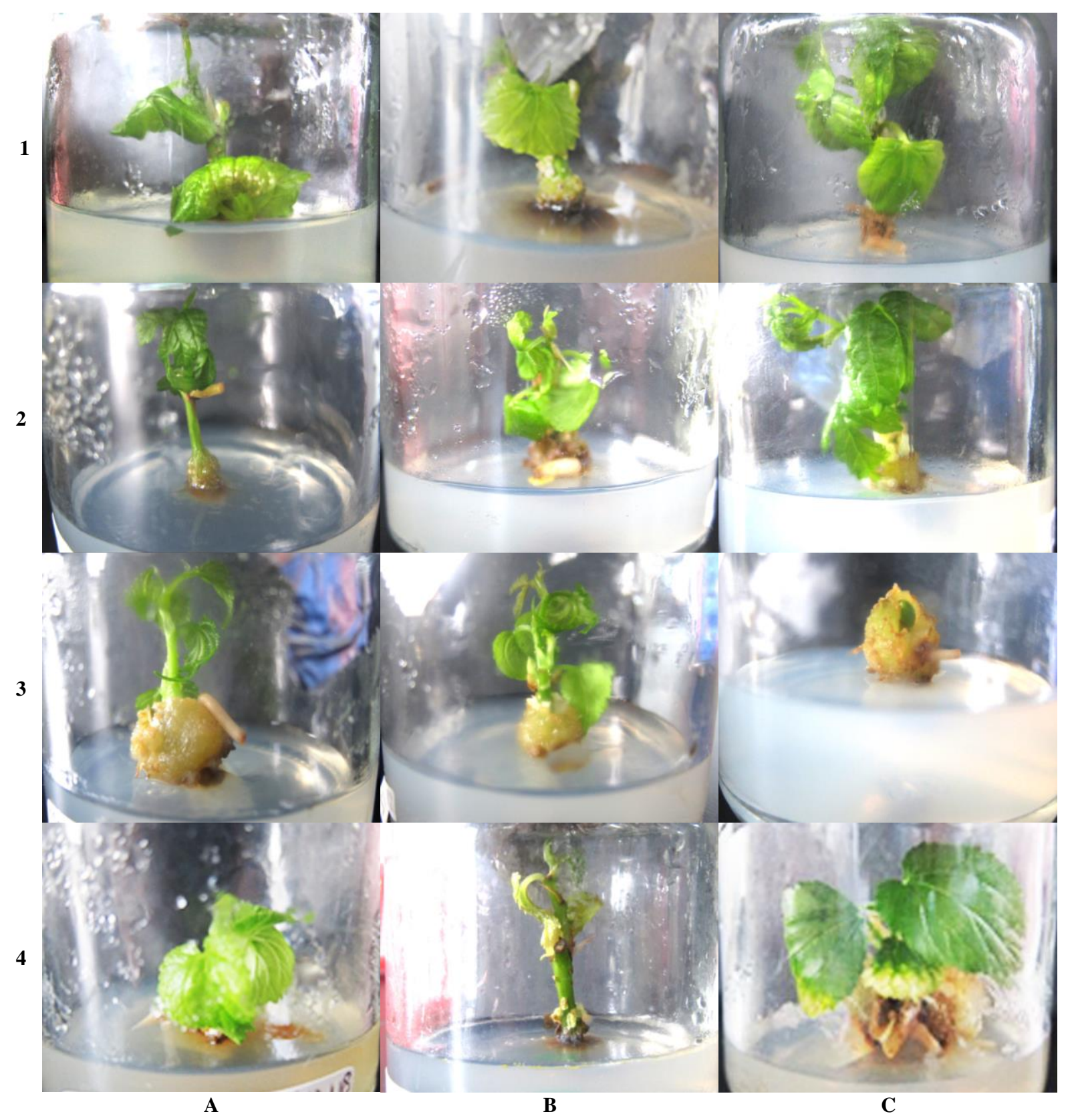

Figure 2. The growth of explants on each concentration of agar-agar. From above to bottom: 1. Morus bombycis var. lembang, 2. Morus cathayana, 3. Morus multicaulis, 4. Morus alba var. kanva-2. From left to right: A. $0.6 \%$, B. $0.8 \%$, B. $1.0 \%$

Almost all Morus spp. showed callus development that led to indirect organogenesis (Table 3). Callus development could affect the axillary bud and make the axillary growth slower. The nutrition that supposed to be used for axillary growth was used for callus development (Anis et al. 2013). Callus development is caused by hyperhydricity state. Hyperhydricity is triggered by many factors like solid substance and environment (Badr-Elen et al. 2012).

Flowering appeared only on the M. bombycis var. lembang after 1 month planting (Figure 3). This result was observed in $0.6 \%$ and $0.8 \%$ agar-agar, hence agar-agar induces the production of the flower hormone in $\mathrm{M}$. bombycis var. lembang.

The number of axillary buds and leaves did not correlate with the length of axillary bud except for $M$. bombycis var. lembang and $M$. cathayana (Table 2). Sometimes uncorrelated result happened because of different water content for each part of plant that was affected by concentration of solid substance (Buah et al. 1999). Each part of the plant needs different rate of nutrition, there is no single medium can give satisfactory results with all tissues used (Reddy et al. 2012). 
Table 3. Effect of agar-agar on micropropagation of Morus spp.

\begin{tabular}{lccc}
\hline \multicolumn{1}{c}{ Species } & $\begin{array}{c}\text { Agar conc. } \\
(\boldsymbol{\%})\end{array}$ & Callus & $\begin{array}{c}\text { Contamination } \\
(\boldsymbol{\%})\end{array}$ \\
\hline M. bombycis var. lembang & 0.6 & Yes & 33.33 \\
& 0.8 & Yes & 0.00 \\
& 1.0 & Yes & 66.67 \\
M. cathayana & 0.6 & Yes & 33.33 \\
& 0.8 & Yes & 33.33 \\
M. multicaulis & 1.0 & Yes & 0.00 \\
& 0.6 & No & 66.67 \\
M. alba var. kanva-2 & 0.8 & No & 66.67 \\
& 1.0 & No & 66.67 \\
& 0.6 & Yes & 0.00 \\
& 0.8 & No & 0.00 \\
& 1.0 & Yes & 0.00 \\
\hline
\end{tabular}

Results are shown as means. Means followed by the same letter in each column of same species are not significantly different at $p<$ 0.05 by One Way ANOVA test

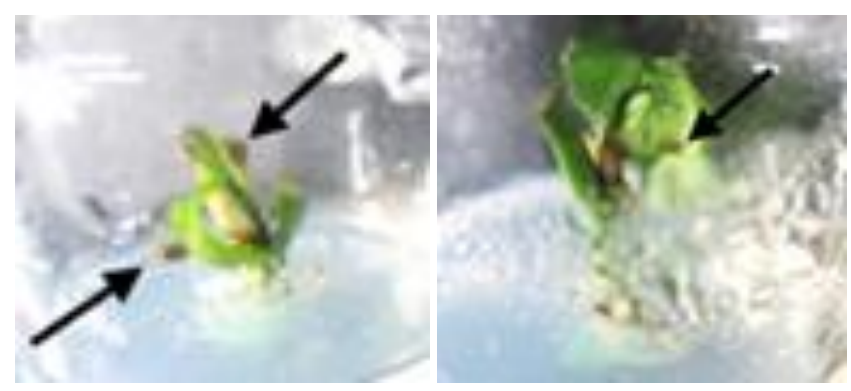

Figure 3. Flowering on Morus bombycis var. lembang with $0.6 \%$ (left) and $0.8 \%$ (right) agar-agar. The flowers are marked by arrow

The highest number of axillary buds was exhibited on $1.0 \%$ agar-agar (M. bombycis var. lembang and $M$. cathayana). M. multicaulis showed the same results for each concentration. $M$. alba var. kanva-2 exhibited the best results at $0.6 \%$ and $0.8 \%$ agar-agar. It showed that the composition of cytokinin might be sufficient. Cytokinin supports axillary bud growth. It activates meristem growth and stem proliferation (Molsaghi et al. 2014; Shende and Manik 2015). Cytokinin intake is more efficient at low concentration of agar-agar. High concentration of agar could inhibit cytokine absorption (Buah et al. 1999). Axillary bud is the best part of micropropagation because it gives the least risk of genetic instability. The growth of axillary bud depends on the age of parent plants where using juvenile plants helps axillary growth. During plant growth from juvenile stage to mature stage, biochemical and physiological changes is occurred (Diego et al. 2010). Mature plants also use nutrition to make more callus than axillary bud (Renau-Morata et al. 2005).

Agar-agar with concentration of $1.0 \%$ maintained the growth of leaves because it contained enough water for photosynthesis. This water content also helps elongation process and inhibits transpiration (Buah et al. 1999). M. multicaulis with $0.8 \%$ and $1.0 \%$ agar-agar did not show any leaves because of the contamination.

$M$. cathayana exhibited the highest growth compared to other species as the growth for each parameter showed the best results. The longest axillary bud showed on $0.8 \%$ agaragar whereas the highest number of axillary buds and leaves showed on $1.0 \%$ agar-agar. Otherwise, $M$. multicaulis did not show good results because of the high contamination rate.

Different species exhibited varying responses for each species because of the genetics. Genetics affected by hormone, however, the same hormone could show a different response for each species. Contamination rate and respond to phenolic compounds also differ (Navroski et al. 2014). Genetic changes could happen on initiation stage. Planting explants might create stress environment and triggered mutagenesis (Kasim et al. 2017).

The highest mortality of plantlets was observed in $M$. multicaulis where it showed high contamination rate. The plant could associate with endophytic or epiphytic fungi. A better result was observed if the parental source was obtained in November. The explant obtained in September was more susceptible to bacterial infection because of the high rate of rainfall (Vijayan et al. 2011). Parental age also affects the contamination rate (Gogoi et al. 2017). The older explant source was more susceptible to contamination. It is important to do research about the best sterilization and an initiation method for M. multicaulis. Adding $\mathrm{HgCl}_{2}$ helps reduce the contamination rate (Vijayan et al. 2011).

Browning also observed on few explants for each species. Almost all M. multicaulis explants exhibited browning. Browning is caused by the oxidation process from releasing explant's phenolic compound to the media. It reduces $\mathrm{pH}$ and inhibited plant growth. Adding ascorbic acid helps to reduce browning (Aga and Khillare 2017). Eliminating brown part from the explant source on sterilization stage and subculturing every two weeks also inhibits plant's death (Jain et al. 2009).

Morus bombycis var. lembang began to show signs of flowering after 40 days of planting (Figure 3). Flowering was observed with $0.6 \%$ and $0.8 \%$ agar-agar supplementation on the medium. It fastens axillary growth (Anis et al. 2013). Flowering signifies good temperature and humidity. The amount of light also supports flowering. The light plays a role as a sucrose regulator to induce florigen (Gogoi et al. 2017).

In conclusion, three concentrations of agar-agar can be used for micropropagation of Morus spp. Agar-agar with concentrations of $0.8 \%$ and $1.0 \%$ showed higher axillary bud, number of axillary buds, and number of leaves compare to $0.6 \%$. M. cathayana showed the best growth compare to other species since it exhibits the highest growth of axillary bud. This species can be cultured well by plant tissue culture using the protocol and agar-agar as a solidifying medium. M. multicaulis did not show good results because of high contamination and browning. Further research was required to compare different kinds of agar-agar as the solid substance and find the significant pathway that regulates plant growth in different rigidity. 


\section{ACKNOWLEDGEMENTS}

This research was financially supported by the Faculty of Biotechnology, Atma Jaya Catholic University of Indonesia research grant. We thank University Farm of IPB University in Sukamantri, Bogor, West Java for providing samples of mulberry plants for this research.

\section{REFERENCES}

Aga E, Khillare Y. 2017. In vitro regeneration of shoots from apical and auxiliary bud explants of Coffea arabica L.. J Med Plants Stud 5 (1): 9-12.

Agustiansyah. 2002. Studi perbanyakan tanaman strawberi (Fragaria ananassa Duch) secara in vitro. [Thesis]. IPB University, Bogor. [Indonesian]

Anggraini YP. 2015. Mikropropagasi Empat Spesies Murbei (Morus spp.) pada Berbagai Konsentrasi Benzyl Amino Purine [Thesis] Universitas Katolik Indonesia Atma Jaya, Jakarta. [Indonesian]

Anis M. Faisal M, Singh SK. 2003. Micropropagation of mulberry (Morus alba L.) through in vitro culture of shoot tip and nodal explants. Plant Tissue Cult 13 (1): 47-51.

Badr-Elden AM, Nower AA, Ibrahim IA, Ebrahim MKH, Elaziem TMA. 2012. Minimizing the hyperhydricity associated with in vitro growth and development of watermelon by modifying the culture conditions. Afr J Biotechnol 11 (35): 8705-8717.

Buah JN, Kawamitsu Y, Sato S, Murayama S. 1999. Effects of different types and concentrations of gelling agents on the physical and chemical properties of media and the growth of banana (Musa spp.) in vitro. Plant Prod Sci 2 (2): 138-145.

Diego ND, Montalban IA, Moncalean P. 2010. In vitro regeneration of adult Pinus sylvestris L. trees. South African J Bot 76: 158-162.

Gangopadhyay G, Roy SK, Mukherjee KK. 2009. Plant response to alternative matrices for in vitro root induction. Afr J Biotechnol 8 (13): 2923-2928

Gogoi G, Borua P, Al-Khayri JM. 2017. Improved micropropagation and in vitro fruiting of Morus indica $\mathrm{L}$. (K-2 cultivar). J Genet Eng Biotechnol 15 (1): 249-256.

Huh YS, Lee JK, Nam SY. 2017. Improvement of ex vitro acclimatization of mulberry plantlets by supplement of abscisic acid to the last subculture medium. J Plant Biotechnol 44: 431-437.

Jain N, Bairu MW, Stirk WA, Van Staden J. 2009. The effect of medium, carbon source and explant on regeneration and control of shoot-tip necrosis in Harpagophytum procumbens. South Afr J Bot 75: 117121
Kasim NFM, Yahya HN, Kadzimin S, Awang Y. 2017. Micropropagation and assessment of genetic variability of Cyclanthus bipartitus. Asian J Plant Sci 17 (1): 19-26.

Krishna H, Alizadeh M, Singh D, Singh U, Chauhan N, Eftekhari M, Sadh RK. 2016. Somaclonal variations and their applications in horticultural crops environment. 3 Biotech 6 (1): 54. DOI: 10.1007/s13205-016-0389-7.

Molsaghi M, Moieni A, Kahrizi D. 2014. Efficient protocol for rapid Aloe vera micropropagation. Pharmaceut Biol 52 (6): 735-739.

Navroski MC, Reiniger LRS, Araujo MM, Curti AR, Pereira MDO. 2014. In vitro establishment and multiplication of genotypes of Eucalyptus dunnii maiden. Cerne 20 (1): 139-146.

Ngezahayo F, Liu B. 2014. Axillary bud proliferation approach for plant biodiversity conservation and restoration. Intl J Biodiver 2014: 727025, DOI: $10.1155 / 2014 / 727025$.

Petrovski S, Tillett D. 2012. Back to the kitchen: food-grade agar is a lowcost alternative to bacteriological agar. Analyt Biochem 429 (2): 140141.

Praiboon J, Chirapart A, Akakabe Y, Bhumibhamon O, Kajiwara T. 2006. Physical and chemical characterization of agar polysaccharides extracted from the Thai and Japanese species of Gracilaria. ScienceAsia 32 (1): 11-17.

Priadi D, Fitriani H, Sudarmonowati E. 2008. Pertumbuhan in vitro tunas ubi kayu (Manihot esculenta crantz) pada berbagai bahan pemadat alternatif pengganti agar. Biodiversitas 9 (1): 9-12.

Reddy SH, Chakravarthu M, Chandrashekara KN. 2012. In vitro multiple shoot induction through axillary bud of Asclepias curassavica L. - a valuable medicinal plant. Intl J Sci Res Publ 2 (8): 1-7.

Renau-Morata B, Ollero J, Arrillaga I, Segura J. 2005. Factors influencing axillary shoot proliferation and adventitious budding in cedar. Tree Physiol 25 (4): 477-486.

Shende CB, Manik SR. 2015. Direct regeneration of shoot from axillary bud of Citrus reticulate. Intl J Agric Technol 11 (6): 1401-1409.

Sulusoglu M. 2014. Effects of agar types on rooting performance in tissue culture: sample of quince a rootstock cultures. Turkish J Agric Nat Sci 1: 957-963.

Tuigong DR, Kipkurgat TK, Madara DS. 2015. Mulberry and silk production in Kenya. Intl J Adv Res 3 (9): 470-481.

Vijayan K, Tikader A, da Silva JAT. 2011. Application of tissue culture techniques for propagation and crop improvement in mulberry (Morus spp.). Tree For Sci Biotechnol 5 (1): 1-13.

Wulandari YRE, Prasasty VD, Rio A, Geniola C. 2019. Determination of 1-deoxynojirimycin content and phytochemical profiles of young and mature mulberry leaves of Morus spp. OnLine J Biol Sci 19 (2): 124131. DOI: $10.3844 /$ ojbsci.2019.124.131.

Yelli F. 2013. Induksi pembentukan kantong dan pertumbuhan dua spesies tanaman kantong semar (Nepenthes spp.) pada berbagai konsentrasi media MS secara in vitro. Agrotropika 18 (2): 56-62. [Indonesian] 